\title{
Politic and Election in Papua Indonesia
}

\author{
Budi Setyanto, Student of the Faculty of Law at Sebelas Maret University, buset papua@yahoo.co.id, \\ ORCID.0000-0007-1990-0197 \\ Jamal Wiwoho, Promotor-1 and Rector of Sebelas Maret Surakarta University, jamalwiwoho@yahoo.com, \\ ORCID.0000-0009-1987-0935 \\ Mohammad Jamin, Promotor-2,Lecturer at Sebelas Maret Surakarta University, jaminmh@yahoo.com, \\ ORCID.0000-0010-1945-0987 \\ Isharyanto,Co-Promotor, Lecturer at Sebelas Maret Surakarta University, masisuns@yahoo.com, ORCID.0000- \\ 0011-1990-0675
}

\begin{abstract}
The general election in Papua is carried out according to the Law No. 7 of 2017 on general election. The general election in Papua employs cultural and tribal approaches through noken system. Despite its violation to the general election principle, the implementation of noken system in the general election brings justice to indigenous people. This research is intended to study about the electoral mechanism in Papua by highlighting the mechanism of indigenous people of Papua. The research finding shows that the law construction of general election in Papua is in line with the customary law that is accommodated by the community in the positive law in Indonesia.
\end{abstract}

Keywords: Politic-Election, Papuan, Indonesia.

Received: 08.12.2020 $\quad$ Accepted: 15.01.2021 $\quad$ Published: 02.02.2021

\section{INTRODUCTION}

Those who live in Central Mountain, Papua, believe in a Noken system that is in facts triggers critics and controversies. It even opened lots of discussion until the last 2018 local election. The parties involved in the local location did not reflect the good values contained in the Noken system. This local system was misused by the election candidates for their own interests. It also applied the transparency principle in which people knew who others voted in the elections. This principle led the opposing party to argue with those who were against it and to countermeasure when defeated (Katharina, 2017).

The local history and culture practice the consensus decision making, the so-called musyarawah which reflects democracy. It is applied by the community to social, political, and other aspects. It is the primary medium used by the government and community to make important decision or policy. For example, the constitutional hierarchy in the village is arranged through musyawarah. Other entities such as social, religion, and education-based organizations also implement this consensus decision making when it comes to resolve their organizational issues.

The 1945 Constitution of the Republic of Indonesia in Article 22E paragraph (2) regulates the election of president and vice president, members of the House of Representatives (DPR), Regional Representative Council (DPD), and Regional House of Representatives (DPRD). DPRD is situated in the provincial and regency/ city levels and its members are selected through the direct election by the local community. They are the communities' representatives who run the government in the provincial and regency/ city levels. They play some important roles, such as to become the regional legislators, to examine and approve the regional government budget, and to implement their supervision function towards the implementation of policies done by the governor, regent, and mayor.

According to the Law No. 7 of 2017 about the general election, political parties participating in the election are elected for DPRD members. Its members are elected through the general election done every five years. Each political party propose DPRD candidates democratically and openly in accordance with the article of association of the political party.

Unlike other provinces in Indonesia, there are two ways of selecting DPRD members in Papua province. Its first election followed the Law No. 7 of 2017 in which the indigenous people and migrants got to choose the candidates proposed by the political parties. However, the second election was carried out 
differently. It was through the appointment mechanism that was regulated in the Special Regional Regulation No. 6 of 2014 about the membership of Papua's House of Representatives (DPRP). The appointment mechanism was carried out to elect one-third of DPRP members from the indigenous people. They are equal to 14 positions out of 56 total membership established for the provincial DPRP.

\section{Research Findings}

For the community who resides in the mountainous area, noken is one of the distinctive cultural objects. It is a symbol of reception, farewell, and gift the central mountain tribe gives to their relatives (Dekme, 2015, pp. 112). Similar to the use of pandan leaves woven bag in Malay community, noken has been the worshipping bag in wedding or funeral. Noken is also used in the communal decision making. Noken system means political commitment, mutual agreement, and support given to certain political candidates. Those who encourage Noken system believe that noken becomes the symbol of community agreement that is derived from the individual decision to support one candidate. It attributes the sovereignty of community in the central mountain of Papua.

\section{DISCUSSION}

Conceptually, people's sovereignty is implemented in the general election. The representatives in the parliament are delegated by the community. They will be asked for their accountability through the mechanism regulated by the law. Experts have different definitions about the general election, yet they have similar substance. According to Rush Michael and Althoff Philips, the general election is a medium to carry out the representative-based sovereignty. In other words, it is a selection and delegation mechanism to which the community gives their authorities. The representatives take control of the government. Therefore, it is expected that the general election can create the representative government. The general election is generally a democratic process to elect the leaders and people's representatives.

Another expert, Jimly Ashidiqie interprets the general election as the organized, democratic method to elect the people's representative. His underlying concept is the representative system in the people's sovereignty or the so-called representative democracy. In its practice, people's representatives in the parliament become the one who implement the sovereignty. They get to decide the method to run the government as well as long and short-term purposes. In order to completely reflect the community, people's representatives must be selected by the community through the general election. In a normative context, the definition of the general election according to the law is people's sovereignty medium to elect president and vice president, members of the House of Representatives (DPR), Regional Representative Council (DPD), and Regional House of Representatives (DPRD) that is conducted in a direct, general, free, secret, honest, and fair manner in accordance with Pancasila and the 1945 Constitution of the Republic of Indonesia.

Numerous definitions of the general election highlight that it is an essential aspect in the implementation of democracy as the sovereignty is in people's hands. The general election ensures that the government has a limited authority by which the democratic country is built. There are two ways of implementing the democratic process in Indonesia. First, it is the general election that is conducted nationally to elect president and vice president, members of the House of Representatives (DPR), Regional Representative Council (DPD), and Regional House of Representatives (DPRD). Second, it is the regional election to elect the governor and vice governor, regent and vice regent, as well as mayor and vice mayor. The general elections that is carried out nationally and regionally are compulsory in every five years.

The importance of general election is it becomes the symbol and benchmark of democracy of a country. It is a statement that people's sovereignty is in their hands and the country is ruled and controlled by people. The highest concept of the general election is that the government's power should be restricted. The general election puts people as the primary sovereignty holders.

The general election to elect the Regional House of Representatives of Papua (DPRP) is based on the Law No. 7 of 2017. It is done simultaneously in all areas of Indonesia every five years. The participants of the general election are political parties which meet the requirement of legal entities, have party's article of association, own central and regional committees, have 30\% representatives, and register in KPU. DPRD candidates are proposed by the political party through a democratic and open selection.

"Masyarakat adat" is translated to "Indigenous People". According to the definition of the Economic and Social Council of the United Nation (in Keraf, 2010: 361), the indigenous people are the tribe and nation 
that, due to its historical continuity with the community before the colonialization, consider themselves different from other groups who live in their area. Ter Haar, in his book entitled Beginselen en Stelsel van het Adatrech, explains the definition of indigenous people. In his definition, the indigenous people are organized group living harmoniously with the government that has material and immaterial objects (free translation). Another definition is given by Hazairin. He gives examples of "desa" in Java, "marga" in South Sumatera, "desa" in Minangkabau, "kuria" in Tapanuli, and "wanua" in South Sulawesi. They are all social units that is facilitated to be independent. It means they have their own law, authority, and environment. They believe in the equal right to the land and water for the community members. The family law such as patrilineal, matrilineal, and bilateral affects the government system, especially when it comes to the agriculture, fishery, and forest products, wild animals work, mining, and handicraft. Every member of community has equal right and obligation. They have communal job which requires plenty of cooperation.

The definition of customary law is mistakenly interpreted with the traditional culture of rural areas. In fact, the law in Indonesia recognizes the customary law as one of the law systems that is implemented side by side with other law systems, such as civil law and Islamic law. There are various definitions of customary law according to some experts. Van Vollenhoven argues that the customary law is a regulation of positive behavior that contains punishment (law) and is not codified ("adat"). It is similar to the definition given by Professor M. M. Djojodigoeno, SH. He explains that the customary law is not derived from the law and regulation.

Based on the various definitions, it is concluded that the applicable law within the community will grow and develop in relation to the culture. Consequently, there are different laws among communities. The values in which the community believe are crystalized in form of customary law. As a result, recognition, respect, and preservation of customary law is compulsory.

Recognition and respect to the existence of indigenous people and their norms within pluralism have been guaranteed by the government. It is part of their protected basic right. It is formulated in the basic norm or positive law norm, namely Article 18B paragraph (2), Article 281 paragraph (2), and Article 32 paragraph (1) of 1945 Constitution of the Republic of Indonesia. Article 18B paragraph (2) states that the State recognizes and respects traditional communities along with their traditional customary right as long as these remain in existence and are in accordance with the societal development and the principles of the Unitary State of the Republic of Indonesia, and shall be regulated by law. In addition, regulations about indigenous people and customary law are made in the Law No. 5 of 1960 on Basic Agrarian Principles, Law No. 32 of 2004 on the Regional Government that is amended by the Law No. 23 of 2014 on the Regional Government that is amended by the Law No. 9 of 2015 about the Second Amendment of the Law No. 23 of 2014 on the Regional Government. Other laws that regulate the existence and right of indigenous people are as follows: The Law No. 41 of 1999 on Forestry, the Law No. 39 of 1999 on the Human Rights, the Law No. 20 of 2003 on the National Educational System, the Law No. 24 of 2003 on Constitutional Court, the Law No. 27 of 2003 on Geothermal, the Law No. 7 o 2004 on Water Resources, the Law No. 18 of 2004 on Agriculture, the Law No. 31 of 2004 on Fishery, the Law No. 26 of 2007 on Spatial Planning, the Law No. 27 of 2007 on Management of Coastal Region and Small Islands, the Law No. 20 of 2009 on Electricity, the Law No. 32 of 2009 on Protection of Living Environment Management, the Law No. 16 of 2014 on Villages, the Law No. 21 of 2001 on Special Autonomy for Papua Province, the Law No. 11 of 2006 on Aceh Government, and the Law No. 13 of 2012 on the Distinction of Daerah Istimewa Yogyakarta.

The indigenous people have rights to conduct political, law, economic, social, and cultural activities. Referring to what Ter Haar says, the indigenous people have holistic, communal, transcendental, and sustainable perspectives. They believe in united and temporal lives. Therefore, the always think about consequences of their present and future conducts. This belief is passed from generation to generation. As a consequence, their existence shall be protected, otherwise their values and professions will be disturbed. In this context, the role of government is very essential to look after their existence. In the political context, the indigenous people of Papua have political right in the pluralism. There are local wisdoms in the political implementation guaranteed by the constitution. They have different implementation which makes them distinctive.

However, there is a contradiction in its practice. "One man one vote" principle in noken system is against the individual freedom and it violates the human right. The general election is carried out in direct and secret manners, so noken system challenges the individual freedom and political right of citizens. Thus, there should be adjustment of political freedom principle and values in noken system. Law synchronization and harmonization to facilitate both parties to meet their interests are obligatory for all. 


\section{CONCLUSION}

In the normative and formal law contexts, noken system implemented in the general election in some regencies/ cities in Central Mountain of Papua Province is considered as the parts of technical application in the applicable election system. In the cultural perspective, the communal decision making is reflected from noken system implemented in various sectors. It is a part of the local culture that has been applied since a long time ago. The reality becomes a fundamental basis to respect and preserve noken system as a local wisdom.

\section{REFERENCES}

Aziz Abdul Hakim. 2015. The State of Law and Democracy in Indonesia, Yogyakarta: Student Library, Second Edition.

Alfian and Syamsuddin, Nasaruddin (ed.). 1988. The Future of Indonesian Political Life. Jakarta: Rajawali Press.

Almond, Gabriel A., and Powell, Jr., Bingham G. 1996. Comparative Politics Today: A World View. New York: Harper Collins College Publishers

Amal, Ichlasul (ed). 1996. Recent Theories of Political Parties. Yogyakarta: Tiara Wacana.

Amirin, Tatang M.1986. Compiling a Research Plan. Jakarta: Rajawali.

Bottomore, Tom. 1992. Political Sociology. Jakarta: Rineka Cipta.

Brewer, Anthony. 2000. Das Kapital Karl Marx. Yogyakarta: Teplok Press.

Brown, M. 1993. "Causes and Implications of Ethnic Conflict" in M. Brown (editor), Ethnic Conflict and International Security. Preinceton: University Press.

Budiarjo, Miriam (editor), 1998. Participation and Political Parties, Jakarta: Yayasan Obor Indonesia

Budiardjo, Miriam. 2008. Basics of Political Science, Jakarta: Gramedia Pustaka Utama, Revised Edition, First Printing.

Bessette, J. M. (1980). Deliberative Democracy: The Majority Principle in Republican Government. Washington: American Enterprise Institute for Public Policy Research.

Dekme, D. (2015). Noken Craftsmen in the Amungme Tribe in Limau Asri Village, Iwaka District, Mimika Regency, Papua Province. HOLISTIC, Journal Of Social and Culture, 8 (16), 1-12. Retrieved from https://ejournal.unsrat.ac.id/index.php/holistik/article/view/8672

Fadil, I. (2017). Papua Bawaslu members value the Noken system needs to be evaluated I merdeka.com. Retrieved October 29, 2019, from https://www.merdeka.com/politik/anggota-bawaslu-papua-nilaisistem-noken-perlu-dievalu.html

Halim, W. (2019). Indonesian Deliberative Democracy; The Concept of Community Participation in Forming Responsive Democracy and Law. Indonesian Society, 42 (June), 19-30. https://doi.org/10.14203/jmi.v42i1.556

Hapsah, Siti Isfardiyana. 2018. Customary Law, Yogyakarta: UII Press Yogyakarta, First Edition.

Haryanto, A. (2017). Six Districts in Papua Will Use the Noken System - Tirto.ID. Retrieved October 29, 2019, from https://tirto.id/enam-kabamatan-di-papua-akan-use-sistem-noken-bW1b

Hamid M. Gaffar, Janedjri. 2013. Democracy and Elections in Indonesia, Jakarta: KonpressCetakan First.

Huda, Ni'matul. 2017. Structuring of Democracy and Elections in Post-Reform Indonesia, Jakarta: Kencana, 1st Edition.

H.R.Warsito. 2017. Cultural Anthropology, Yogyakarta: Waves, Say two.

Jamin, Mohammad, Adat Court. 2014. A Shift in Legal Politics, Perspective of the Special Autonomy Law for Papua, Yogyakarta: Graha Ilmu, First Printing.

Journal Politika, 1 (1), 1-7. Retrieved from https://ojs.unud.ac.id/index.php/politika/article/view/21390

Jafrianto, J. (2016). The existence of the Election with the Citizens' Agreement Model in the General Election System in Indonesia (Review of Constitutional Court Decisions Number 47-81 / phpu.a-vii / 2009 concerning Disputes over General Election Results). Student Online Journal of the Faculty of Law, University of Riau, III (2), 1-15. Retrieved from https://www.n Research.com/publications/187556/eksisten-pementuk-dengan-model-citizen-agreement-inelection-system

Juanda. 2008. Local Government Law, the Ups and Downs of the Relationship of Authority between DPRD and Regional Heads, Bandung: ALUMNI Bandung, 1st edition Second Edition. 
M. Gafar Janejri. 2013. Democracy and Elections in Indonesia, Jakarta: Kompress.

Mulle, Kal. 2008. Getting to know Papua, Indonesia: Daysy World Books, First Edition ,.

Mahfud, Moh.MD. 2003. Democracy and the Indonesian Constitution, Studies on Political Interaction and the Life of the State Administration. Jakarta: Rineka Cipta, Second Edition ,.

Mahfud, Moh.MD. 2017. Structuring Democracy \& Elections in Post-Reform Indonesia, Jakarta: Kencana, 1st Edition.

Research Team, Department of Politics and Government UGM, Final Report on Asymmetrical Decentralization that Makes Welfare: Aceh and Papua (Yogyakarta: Department of Politics and Government, Gadjah Mada University, 2012)

Pemilukada Research Team at the LIPI Political Research Center (Dr. Kurniawati Hastuti Dewi, Prof. Dr. Indria Samego, Dra. Sri Nuryanti, MA., Drs. Afadlal, MA., Pandu YusinaAdaba S.Ip., Dini Suryani, S.Ip), Evaluation of Pemilukada Format Towards Good and Effective Regional Government at the Provincial level, Policy Paper, LIPI Political Research Center, Jakarta, 2013, has not been published.

Pemilukada Research Team at the LIPI Political Research Center (Prof. Dr. Indria Samego, Dra.Sri Nuryanti, MA, Dr. Tri Ratnawati, Drs.Afadlal, MA, Pandu Yusina Adaba S.Ip., Dini Suryani S.Ip), "Evaluation of Pilukada Practices Directly in the Regency / City and some suggestions for future improvements, "Executive Summary, Jakarta, 2012.

Tarima, Y., Noak, P. A., \& Azhar, M. A. (2016). The Role of Tribe Heads in the Noken System in the Regional Head Election in KAMU District, Dogiyai District, Papua Province in 2013. E- 